\title{
Modelling the variation in wood density of New Zealand-grown Douglas-fir
}

\author{
Mark O. Kimberley, Russell B McKinley, David J. Cown and John R. Moore* (0)
}

\begin{abstract}
Background: Wood density is an important property that affects the performance of Douglas-fir (Pseudotsuga menziesii (Mirb.) Franco) timber. In order to develop strategies to achieve certain end-product outcomes, forest managers and wood processors require information on the variation in wood density across sites, among trees within a stand and within trees. Therefore, the aim of this study was to develop models explaining the variation in outerwood density among sites and among trees within a stand, and the radial and longitudinal variation of wood density within a tree.

Methods: An extensive dataset was assembled containing wood density measurements from historical studies carried out over a period spanning more than 50 years. The dataset contained breast height outerwood density cores from approximately 10,800 individual trees sampled from 312 stands throughout New Zealand, pith-to-bark radial density profiles from 515 trees from 47 stands, and discs taken from multiple heights in 172 trees from 21 stands. Linear and non-linear mixed models were developed using these data to explain the variation in inter- and intra-tree variation in Douglas-fir wood density.

Results: Breast height outerwood density was positively related to mean annual air temperature in stands planted after 1969. This relationship was less apparent in older North Island stands, possibly due to the confounding influences of genetic differences. After adjusting for age and temperature, wood density was also positively related to soil carbon (C) to nitrogen $(\mathrm{N})$ ratio in South Island stands where data on soil C:N ratio were available. There was only a minimal effect of stand density on breast height outerwood density, and a weak negative relationship between wood density and tree diameter within a stand. Within a stem, wood density decreased over the first seven rings from the pith and gradually increased beyond ring ten, eventually stabilising by ring 30. Longitudinal variation in wood density exhibited a sigmoidal pattern, being fairly constant over most of the height but increasing in the lower stem and decreasing in the upper stem.

Conclusions: The study has provided greater insight into the extent and drivers of variation in Douglas-fir wood density, particularly the relative contributions of site and silviculture. The models developed to explain these trends in wood density have been coupled together and linked to a growth and yield simulator which also predicts branching characteristics to estimate the impact of different factors, primarily site, on the wood density distribution of log product assortments. Further work is required to investigate the impacts of genetic and soil properties on wood density, which may improve our understanding of site-level variation in wood density.
\end{abstract}

Keywords: Wood density, Pseudotsuga menziesii, Simulation models, Wood quality, Site effects, Silviculture

\footnotetext{
* Correspondence: john.moore@scionresearch.com
}

Scion, Private Bag 3020, Rotorua 3046, New Zealand 


\section{Background}

Douglas-fir (Pseudotsuga menziesii (Mirb.) Franco) is native to the coastal and interior regions of western North America, from west-central British Columbia southward to central California (Pojar and MacKinnon 1994). It produces a highly regarded timber preferred for its superior strength, toughness, durability and decay resistance (Barrett and Kellogg 1991). As well as being popular for light timber framing, larger dimensions are highly sought after for use in exposed interior posts and beams because of the species' good stability and low incidence of twist. Outside of its native range, Douglasfir is an important exotic species in western and central Europe, particularly in France, Germany, the Czech Republic, and Belgium. It was first planted in New Zealand in 1859 (Maclaren 2009), and the coastal variety of Douglas-fir (var. menziesii) is now the country's second most important plantation species with a total planted area of approximately 105,000 ha (Ministry for Primary Industries 2014).

Early work by wood scientists and silviculturalists working on the utilisation of New Zealand-grown Douglas-fir established that the single most important factor influencing timber stiffness was branching, and the next most important, wood density (Whiteside et al. 1976). Together, density and branch size explained around $80 \%$ of the observed variation in timber stiffness (Tustin and Wilcox 1978; Whiteside 1978). The fact that growth rate was shown to have only a modest impact on density and stiffness (Harris 1978) led to the recommendation that Douglas-fir should be grown as rapidly as possible on a short rotation, subject to maintaining a small branch index and an average wood density above $400 \mathrm{~kg} \mathrm{~m}^{-3}$.

Management of Douglas-fir stands to achieve particular end product outcomes requires information on how wood density and branch characteristics are affected by site, silviculture and genetics. Quantitative knowledge of the variation in wood density among sites, among trees within a stand and within a tree is also needed. Information on branch characteristics in this species has been used to develop models that can be coupled to growth and yield modelling systems in order to study the impacts of silviculture on log and timber quality (Grace et al. 2015; Maguire et al. 1999; Maguire et al. 1991). Considerable information on Douglas-fir wood density has been collected in studies undertaken in New Zealand, North America and Europe. A series of studies in Canada and the United States examined the implications of silviculture on wood density and the proportion of corewood (juvenile wood) within a tree (Filipescu et al. 2014; Jozsa and Brix 1989; Kellog 1989; Stoehr et al. 2009; Vargas-Hernandez and Adams 1994; Vikram et al. 2011; Wellwood 1952). Regional differences in Douglasfir wood density have also been identified that are related to elevation, temperature, rainfall, and soil properties (Cown and Parker 1979; Filipescu et al. 2014; Kantavichai et al. 2010a; Maeglin and Wahlgren 1972; USDA 1965). A trend of increasing wood density with decreasing summer rainfall and decreasing elevation was observed by Lassen and Okkonen (1969), while Filipescu et al. (2014) found wood density increased with temperatue. Climatic factors, particularly temperature and rainfall, affect wood density through their impact on the xylem cell production, radial expansion and secondary thickening (Antonova and Stasova 1997). This, in turn, affects the transition from earlywood to latewood formation within an annual ring. The timing of this transition affects the proportion of latewood within an annual ring as does the amount of growth that occurs during the period that latewood is being produced. Summer temperature has been observed to be positively associated with latewood proportion and average latewood density in a range of species, including Douglas-fir (Filipescu et al. 2014; Jordan et al. 2008; Kantavichai et al. 2010a; Wilhelmsson et al. 2002; Wimmer and Grabner 2000).

In New Zealand, a survey of 30- to 40-year-old Douglas-fir stands growing on 19 sites throughout the country revealed a high degree of variation among trees, a latitudinal effect, and a possible influence of provenance (Harris 1966). However, no attempt was made to investigate whether site differences were associated with climatic variables. Early studies in New Zealand-grown Douglas-fir also revealed a high degree of tree-to-tree variation in wood density, which prompted the suggestion that this property could be used as a selection criterion thereby significantly improving the yield of good quality structural timber (Harris 1967, 1978).

Models describing the radial variation in Douglas-fir wood density have been developed in several North American studies (e.g. Filipescu et al. 2014; Kantavichai et al. 2010a; Kantavichai et al. 2010b), but up until now similar models have not been produced for Douglas-fir in New Zealand. However, data suitable for developing such models have been collected and are described in several published studies (Cown 1999; Harris 1966; Knowles et al. 2003; Lausberg 1996; Lausberg et al. 1995) and numerous unpublished studies. Similar data for New Zealand-grown radiata pine (Pinus radiata D. Don) have recently been used to develop models explaining both site-level (Palmer et al. 2013) and intra-stem (Kimberley et al. 2015) variation in wood density, and the influence of genetic improvement (Kimberley et al. 2016). Together these models have been implemented in the Forecaster growth and yield simulator (West et al. 2013), enabling forest managers to analyse the effects of different combinations of site and silviculture on wood density.

The objective of this study was to develop comprehensive models describing the variation in New Zealand- 
grown Douglas-fir wood density at the regional (among site), inter-tree and intra-tree scales, and to identify the factors associated with this variation. These models were derived from the extensive database assembled from previous studies, with some additional new data collected from regions where historical coverage was poor. They have been implemented within the Forecaster growth and yield prediction system (West et al. 2013), so that forest managers will be able to predict stem and log densities as functions of site, stand age and silvicultural regime.

\section{Methods}

\section{Data sources}

Wood density data were assembled from studies carried out over a more than 50 year period between 1958 and 2014. A wood density database was created from existing sources of data by collating density values from numerous historical studies, both published and unpublished. This database included the following types of data: (1) outerwood increment cores - basic density of the outer $50 \mathrm{~mm}$ of the stem (to allow analysis of site, stand age and climatic variables influencing density); (2) individual ring-level values of density from X-ray densitometry (to provide ring-level radial trends in wood density); and (3) whole-disc density values from felled trees (to enable prediction of log and stem values as well as the longitudinal trend in wood density within a stem).

\section{Outerwood density data}

Outerwood density data were obtained by searching Scion databases along with published and unpublished reports. Priority was given to studies where the location of stands was known in terms of elevation, latitude and longitude, along with age. Information on outerwood density was obtained from approximately 10,800 trees (usually two increment cores per tree) sampled in 312 stands aged between 15 and 70 years (Table 1; Fig. 1). Stands less than 15 years old were not considered as the focus of these studies was on characterising wood density in merchantable trees, either through pre-commercial thinning or final harvesting. Stands were on sites that spanned a latitudinal range from $37.9^{\circ}$ to $46.2^{\circ}$ south, and ranged in elevation from $60 \mathrm{~m}$ up to $1200 \mathrm{~m}$ a.s.l. The average site elevation was $485 \mathrm{~m}$ in the North Island and $430 \mathrm{~m}$ in the South Island. The data represent Douglas-fir stands from throughout New Zealand planted in three main periods; $37 \%$ were planted before 1940, mainly in the 1920s and 1930s, 51\% between 1940 and 1969, and a smaller group of $12 \%$ planted after 1969. In all studies, basic density was calculated for outerwood core samples (50 $\mathrm{mm}$ from the bark inwards) using the maximum moisture content method (Smith 1954).

In most cases, only stand mean values were available but density measurements for individual trees were available for a subset of the data consisting of 1489 trees from 55 stands. In most of these stands, one core was taken per tree, but in 20 stands, two cores were taken per tree avoiding the underside of any lean. These data were used to investigate the distribution and variation in wood density among trees within a stand. In a subset of 29 stands containing 883 trees, breast height diameter $(\mathrm{DBH}-1.4 \mathrm{~m})$ was also available allowing analysis of the within-stand relationship between $\mathrm{DBH}$ and outerwood density.

The coordinates of each stand were used to extract annual and seasonal (spring, summer, autumn and winter) mean values for a wide range of climate variables from spatially-interpolated climate normals developed by the National Institute for Water and Atmospheric Research. Variables extracted included various measures of temperature (annual mean, mean daily minimum and maximum), rainfall, solar radiation and vapour pressure deficit. Soil carbon $(\mathrm{C})$ and nitrogen $(\mathrm{N})$ concentrations sampled from the upper $0-5 \mathrm{~cm}$ of mineral soil were available for a small subset of 18 South Island stands within the database from a study carried out in 2011.

\section{Pith-to-bark radial density data}

Pith-to-bark radial profiles of ring-level wood density were available for more than 500 trees from 47 stands (Table 1). Breast height pith-to-bark core samples (5 $\mathrm{mm}$ in diameter) were collected from each tree and Soxhlet extracted with methanol to remove extractives and resin. Strips were milled from these cores and scanned using the X-ray densitometer at Scion (Cown and Clement 1983).

\section{Whole disc data}

Area-weighted wood density values of discs cut at intervals from stems of 172 felled trees in 21 stands were used to establish within-stem longitudinal patterns of wood density for New Zealand Douglas-fir (Table 1). Only trees greater than $25 \mathrm{~m}$ in height were used in this analysis. Wood density of each disc was assessed gravimetrically in 5-ring groups from the pith outwards and combined to provide an estimate for the disc. The dataset included field samples from 51 trees in five stands from the southern South Island collected for this study during 2014. These additional samples were deemed necessary as over $75 \%$ of the Douglas-fir resource is currently located in the South Island, with approximately $50 \%$ in the Otago and Southland regions (Ministry for Primary Industries 2014), due mainly to its better performance than other species on snow prone sites and issues with Swiss Needle Cast caused by Phaeocryptopus gaeumannii in North Island stands (Stone et al. 2007). 
Table 1 Summary of the different sources of wood density data collected for New Zealand-grown Douglas-fir

\begin{tabular}{|c|c|c|c|c|c|c|c|c|c|c|c|c|c|c|}
\hline \multirow[t]{3}{*}{ Region } & \multicolumn{4}{|c|}{ Outerwood density } & \multicolumn{5}{|c|}{ Pith-to-bark densitometry profiles } & \multicolumn{5}{|c|}{ Felled tree data } \\
\hline & \multirow{2}{*}{$\begin{array}{l}\text { No. of } \\
\text { stands }\end{array}$} & \multicolumn{3}{|c|}{ Age (years) } & \multirow{2}{*}{$\begin{array}{l}\text { No. of } \\
\text { stands }\end{array}$} & \multirow{2}{*}{$\begin{array}{l}\text { No. } \\
\text { of } \\
\text { trees }\end{array}$} & \multicolumn{3}{|c|}{ Age (years) } & \multirow{2}{*}{$\begin{array}{l}\text { No. of } \\
\text { stands }\end{array}$} & \multirow{2}{*}{$\begin{array}{l}\text { No. } \\
\text { of } \\
\text { trees }\end{array}$} & \multicolumn{3}{|c|}{ Age (years) } \\
\hline & & Mean & Min & $\operatorname{Max}$ & & & Mean & Min & $\operatorname{Max}$ & & & Mean & Min & $\operatorname{Max}$ \\
\hline \multicolumn{15}{|l|}{ North Island } \\
\hline Bay of Plenty & 135 & 44 & 16 & 70 & 10 & 122 & 35 & 20 & 52 & 9 & 61 & 37 & 31 & 62 \\
\hline Waikato & 40 & 33 & 25 & 59 & 3 & 25 & 57 & 52 & 59 & 3 & 57 & 58 & 54 & 59 \\
\hline Other North Island & 7 & 38 & 29 & 52 & 2 & 20 & 47 & 42 & 52 & 0 & 0 & - & - & - \\
\hline \multicolumn{15}{|l|}{ South Island } \\
\hline Tasman/Nelson & 44 & 34 & 17 & 54 & 3 & 30 & 37 & 28 & 52 & 1 & 1 & 24 & 24 & 24 \\
\hline Canterbury & 50 & 35 & 15 & 62 & 18 & 156 & 36 & 18 & 62 & 2 & 11 & 46 & 27 & 48 \\
\hline Otago & 14 & 31 & 16 & 52 & 11 & 162 & 26 & 14 & 40 & 2 & 3 & 45 & 44 & 46 \\
\hline Southland & 22 & 35 & 24 & 57 & 0 & 0 & - & - & - & 4 & 39 & 49 & 40 & 67 \\
\hline Overall & 312 & 39 & 15 & 70 & 47 & 515 & 35 & 14 & 62 & 21 & 172 & 48 & 24 & 67 \\
\hline
\end{tabular}

\section{Effect of environmental and stand variables on} outerwood density

All statistical analyses and modelling performed in this study were carried out using SAS Version 9.3 statistical analysis software (SAS Institute Inc. 2011). The first analysis was concerned with the effects of site and stand

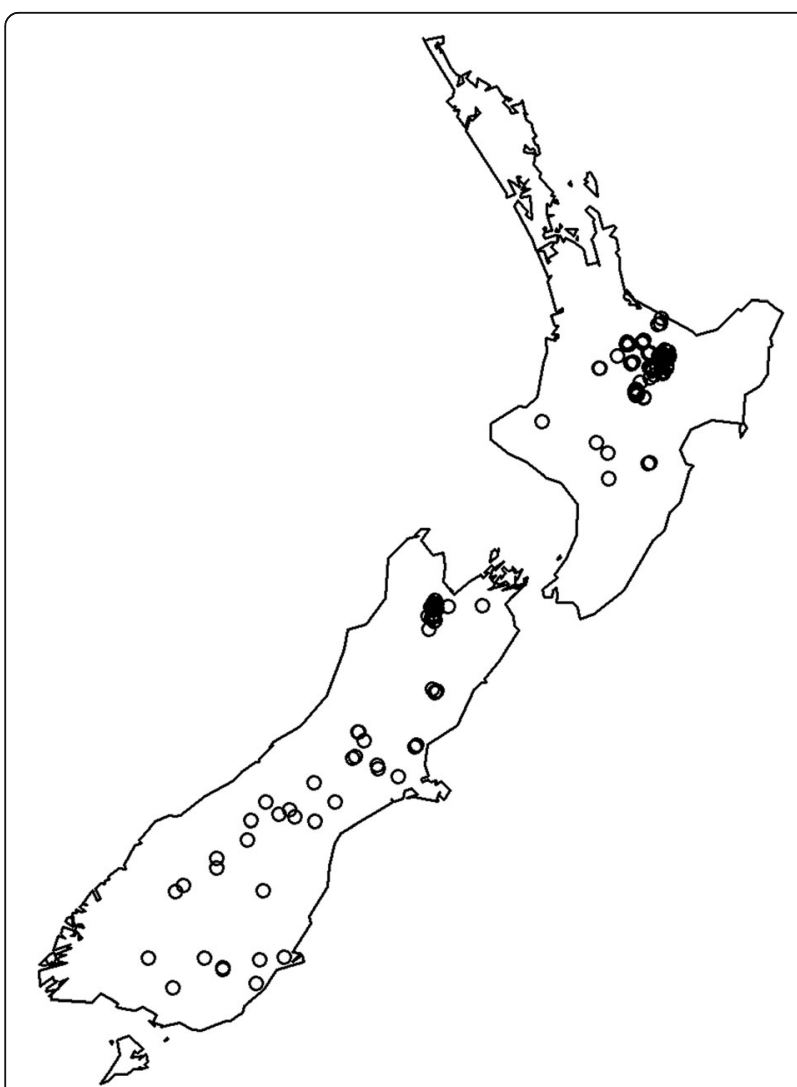

Fig. 1 Map of New Zealand showing the location of the 312 stands where breast height outerwood density data were collected variables on the average outerwood density of a stand. Relationships between outerwood density and stand age, latitude, longitude, elevation, the climate variables extracted from spatially-interpolated climate normals, and for the small subset where it was available, soil C:N ratio, were explored through correlation analysis using the SAS CORR procedure. To eliminate the effect of stand age, partial correlations with environmental variables adjusted for age were calculated. Regression models were then fitted to predict outerwood density as a function of stand age and mean annual temperature (MAT) which proved to be the best overall climate variable. As stand age had a nonlinear (exponential) relationship with density, the final regression model fitted using the SAS NLIN procedure was as follows:

$$
\operatorname{Dow}_{i}=a+b \times M A T_{i}-c \times \exp \left(-d \times A g e_{i}\right)+e_{i}
$$

Where $D_{0} w_{i}$ is mean breast height outerwood density of stand $i\left(\mathrm{~kg} \mathrm{~m}^{-3}\right), A g e_{i}$ is stand age (years), $M A T_{i}$ is mean annual temperature $\left({ }^{\circ} \mathrm{C}\right), a, b, c$ and $d$ are model parameters, and $e_{i}$ is the error term. The stand age component of Eq. (1) can be used to adjust any outerwood density measurement to a common age of 40 years. This is achieved by adding the following term to an outerwood density measurement:

$$
\text { Age_adjustment }=c[\exp (-d \times A g e)-\exp (-d \times 40)]
$$

The outerwood density dataset included results from ten stocking trials (three in the North Island and seven in the South Island), providing the opportunity to examine the influence of stand density on wood density. Each trial contained between two and four levels of stand density, with the minimum stand density averaging 345 stems ha $^{-1}$ (range 250-980 stems $\mathrm{ha}^{-1}$ ) and the maximum averaging 
1330 stems ha $^{-1}$ (range 740-2700 stems ha ${ }^{-1}$ ). On average, 20 trees were assessed in each treatment (range 10-30 trees) and the average stand age at the time of assessment was 31 years (range 18-40 years). The data were analysed using the following model fitted with the SAS GLM procedure:

$$
\operatorname{Dow}_{i j}=a_{\mathrm{i}}+b \times N_{i j}+e_{i j}
$$

Where Dow $_{i j}$ is mean breast height outerwood density $\left(\mathrm{kg} \mathrm{m}^{-3}\right)$ of plot $j$ in trial $i, N_{i j}$ is stand density $\left(\right.$ stems ha $\left.{ }^{-1}\right)$, $a_{i}$ and $b$ are model parameters, and $e_{i j}$ is the error term.

\section{Within-stand variation between trees}

The distribution of outerwood density between trees within a stand was examined using the SAS UNIVARIATE procedure. The coefficient of variation (i.e., the ratio of the standard deviation to the mean value) for outerwood density was calculated for each stand. In stands where DBH measurements were available, the pooled withinstand correlation coefficient between outerwood density and DBH was calculated using the SAS DISCRIM procedure. Using data from stands where two outerwood cores were taken per tree, it was possible to separate out the small-scale variability of cores within a tree from the general variation between trees using variance component analysis carried out using the SAS MIXED procedure.

\section{Within-stem radial pattern in wood density}

A regression model expressing density as a function of ring number from pith was used to model the pith-tobark radial pattern in wood density. The model predicts Dring $_{i R}$, the mean breast-height density $\left(\mathrm{kg} \mathrm{m}^{-3}\right)$ of the $R^{\text {th }}$ ring from pith in stand $i$ :

$$
\begin{aligned}
\text { Dring }_{i R}=a & +(b-R) /(c+d \times \exp (f \times R)) \\
& +(1-g \times \exp (-h \times R)) \times L_{i}+e_{i R}
\end{aligned}
$$

The first part of this model describes the radial pithto-bark pattern in mean density as a function of ring number, $R$, while the second part accounts for random variation between stands and includes a local parameter $L_{i}$ to calibrate the model for each individual stand. When $L_{i}$ is zero, the model predicts density for an average stand, while a negative value of $L_{i}$ is appropriate for a lower density stand, and a positive value for a higher density stand. The parameters in the model were estimated using the SAS NLMIXED procedure, with $L_{i}$ treated as a normally distributed random term varying between stands with variance $\sigma_{s \tan d}^{2}$, and a within-radial error term $e_{i R}$ with variance $\sigma_{e}^{2}$.

\section{Within-stem longitudinal pattern in wood density}

Examination of the disc data indicated that a better relationship between wood density and height-within-stem would be obtained if density was predicted using relative height (i.e. the height of a disc in the stem divided by total stem length, (disc height)/(tree height)) rather than absolute height. However, tree heights were measured in only a minority of the felled tree studies and it was therefore necessary to estimate tree height where this had not been measured. This was achieved by fitting quadratic regression models predicting disc diameter from height for each stem. Tree height was then estimated for each stem by extrapolating this model to a diameter of zero. These regression models were fitted using data from discs cut at greater than $5 \mathrm{~m}$ height, as above this height, stem taper was found to be well approximated by a quadratic model. Only trees with diameter of the highest disc less than $200 \mathrm{~mm}$, and where the uppermost disc height was at least $70 \%$ of the estimated tree height, were used. Actual measured tree height was available for 70 trees in the database, and it was therefore possible to validate the procedure against these measured heights. The mean error (actual - estimated height) was $0.03 \mathrm{~m}$ with standard deviation $0.9 \mathrm{~m}$, and the correlation between measured and estimated height was 0.99 . Based on this validation, the procedure was judged to perform well. Using estimated tree height, the relative height of each disc was calculated.

A model was then derived for predicting whole-disc density as a function of relative height. A polynomial model form with an additive random effect for each tree was found to be suitable. By plotting disc density against relative height, it was apparent that density has a sigmoidal pattern with relative height, well approximated by a cubic function. The following regression model was therefore fitted to predict average disc density at the $k^{\text {th }}$ height in tree $j$ in stand $i, \operatorname{Ddisc}_{i j k}\left(\mathrm{~kg} \mathrm{~m}^{-3}\right)$, as a function of relative height $\left(\right.$ Hrel $\left._{i j k}\right)$ :

$$
\begin{aligned}
\text { Ddisc }_{i j k}=a & +b \times \text { Hrel }_{i j k}+c \times \text { Hrel }_{i j k}^{2}+d \\
& \times \text { Hrel }_{i j k}^{3}+L_{\mathrm{i}}+T_{\mathrm{ij}}+e_{i j k}
\end{aligned}
$$

The parameters in the model were estimated using the SAS MIXED procedure, with local stand parameter $L_{i}$ treated as a normally distributed random term varying between stand with variance $\sigma_{s t a n d}^{2}$, a tree effect $T_{i j}$ treated as a normally distributed random term with variance $\sigma_{t r e e(s \tan d)}^{2}$, and a within-tree error term $e_{i j k}$ with variance $\sigma_{e}^{2}$. There was no trend in the variance between trees with relative height and the random stand, tree and random terms were therefore represented as an additive effects in the model.

\section{Linking models to a growth and yield simulator}

The wood density models described in this paper have been implemented within the Forecaster growth and 
yield simulator (West et al. 2013) allowing forest managers to analyse the effects of different combinations of site and silviculture on wood density (see Appendix for details). To demonstrate the utility of these coupled growth and wood density models, we predicted the growth and wood density for stands growing at three different sites: $(1)$ southern South Island $\left(M A T=8{ }^{\circ} \mathrm{C}\right)$; (2) northern South Island $\left(M A T=10{ }^{\circ} \mathrm{C}\right)$; and (3) North Island $\left(M A T=12{ }^{\circ} \mathrm{C}\right)$. At each site, two different silvicultural regimes were simulated: (1) initial planting density of 1667 trees $\mathrm{ha}^{-1}$, pre-commercial thinning to a residual stand density of 750 trees $\mathrm{ha}^{-1}$ at mean top height of $14 \mathrm{~m}$ and commercially thinned to a residual stand density of 325 trees $^{-1}$ at mean top height $22 \mathrm{~m}$ (a typical regime for Douglas-fir in New Zealand); and (2) initial planting density of 1250 trees $\mathrm{ha}^{-1}$, precommercial thinning to a residual stand density of 400 trees $\mathrm{ha}^{-1}$ at mean top height of $14 \mathrm{~m}$ (a more aggressive early thinning regime). For each site and silvicultural regime combination, the breast height outerwood density and whole log average wood density was predicted for four different harvest ages $-35,40,45$ and 50 years. Whole $\log$ values were calculated over a $5 \mathrm{~m}$ log length and up to four logs were cut from each tree. Site productivity metrics and growth information used to initialise the Forecaster growth and yield prediction system were obtained from Scion's Permanent Sample Plot database (Hayes and Andersen 2007).

\section{Results}

\section{Effects of site and environment on outerwood density}

Average breast height outerwood density in the 312 stands sampled from across New Zealand was $427 \mathrm{~kg} \mathrm{~m}^{-3}$, with a standard deviation of $35.8 \mathrm{~kg} \mathrm{~m}^{-3}$ giving a coefficient of variation of $8.4 \%$ (Table 2). There were significant positive correlations between outerwood density and stand age for both North and South Islands (Table 3). For the North Island stands, partial correlations adjusted for stand age showed weak but statistically significant relationships between wood density and elevation (negative), and MAT (positive). South Island stands showed much stronger associations between outerwood density and air temperature, with a partial correlation adjusted for age of 0.72 for MAT. Although all the temperature variables tested were positively associated with density, correlations were strongest for winter temperatures and weakest for summer temperatures (e.g., the partial correlations for winter and summer mean temperature were 0.72 and 0.57 respectively). There were weaker correlations with a number of other variables including rainfall and elevation, although after accounting for age and MAT, partial correlations with these variables became non-significant. The small number of stands where soil carbon $(\mathrm{C})$ and nitrogen $(\mathrm{N})$ were sampled provided strong evidence of a positive relationship between density and soil C: $\mathrm{N}$ ratio.

Outerwood densities were also analysed in relation to the three main planting periods represented in the dataset (i.e., pre-1940, 1940-1969, and post-1969). It is likely that the genotypes represented within each planting period and within each island varied, potentially obscuring environmental effects on wood density. An analysis of covariance was used to estimate mean outerwood density for each period in each island, using as covariates $M A T$, stand age, and age-squared (included because the relationship between age and density was clearly nonlinear). Adjusting for the effects of age and temperature, North Island stands planted before 1970 had significantly lower average outerwood density (by about $50 \mathrm{~kg} \mathrm{~m}^{-3}$ ) than South Island stands or post-1969 North Island stands (Table 4).

Examination of the relationship between breast height outerwood density and stand age indicated that it typically increases with age before stabilising after about age 30 years. The increased density in the inner seven rings apparent in detailed densitometry data (see the following section) was not evident in the outerwood density data

Table 2 Summary of breast height outerwood density values by region

\begin{tabular}{|c|c|c|c|c|c|}
\hline \multirow[t]{2}{*}{ Region } & \multirow[t]{2}{*}{ No. of stands } & \multicolumn{4}{|c|}{ Breast height outerwood density $\left(\mathrm{kg} \mathrm{m}^{-3}\right)$} \\
\hline & & Mean & Std. dev. & Min. & Max. \\
\hline \multicolumn{6}{|l|}{ North Island } \\
\hline Bay of Plenty & 135 & 430 & 29.3 & 326 & 500 \\
\hline Waikato & 40 & 405 & 28.0 & 373 & 477 \\
\hline Other North Island & 7 & 445 & 33.0 & 403 & 491 \\
\hline \multicolumn{6}{|l|}{ South Island } \\
\hline Tasman/Nelson & 44 & 445 & 32.0 & 368 & 505 \\
\hline Canterbury & 50 & 424 & 44.6 & 324 & 520 \\
\hline Otago & 14 & 393 & 47.7 & 319 & 483 \\
\hline Southland & 22 & 438 & 29.8 & 381 & 532 \\
\hline Overall & 312 & 427 & 35.8 & 319 & 532 \\
\hline
\end{tabular}


Table 3 Correlations and partial correlations between breast height outerwood density and various site and environmental variables

\begin{tabular}{|c|c|c|c|c|c|c|}
\hline \multirow[t]{2}{*}{ Variable } & & \multicolumn{2}{|c|}{ North Island $(n=182)$} & \multicolumn{3}{|c|}{ South Island $(n=130)$} \\
\hline & & $r^{a}$ & $r_{\text {age }}^{b}$ & $r^{a}$ & $r_{\text {age }}^{\mathrm{b}}$ & $r_{\text {age,MAT }}^{c}$ \\
\hline \multicolumn{2}{|l|}{ Stand age (years) } & $0.37^{* *}$ & - & $0.53^{* *}$ & - & - \\
\hline \multicolumn{2}{|l|}{ Latitude (deg.) } & -0.14 & -0.09 & $0.19^{*}$ & $0.29^{* *}$ & 0.11 \\
\hline \multicolumn{2}{|l|}{ Longitude (deg.) } & 0.13 & 0.05 & $0.28^{* *}$ & $0.38^{* *}$ & $0.19^{*}$ \\
\hline \multicolumn{2}{|l|}{ Elevation (m) } & $-0.22^{* *}$ & $-0.22^{*}$ & $-0.47^{* *}$ & $-0.51^{* *}$ & -0.06 \\
\hline \multicolumn{2}{|l|}{ Mean annual rainfall (mm) } & -0.13 & -0.03 & $-0.20^{*}$ & $-0.26^{* *}$ & 0.07 \\
\hline \multirow[t]{5}{*}{ Mean temperature $\left({ }^{\circ} \mathrm{C}\right)$} & Annual & $0.19^{* *}$ & $0.21^{* *}$ & $0.57^{* *}$ & $0.72^{* *}$ & - \\
\hline & Spring & 0.12 & 0.14 & $0.56^{* *}$ & $0.68^{* *}$ & -0.04 \\
\hline & Summer & 0.14 & $0.16^{*}$ & $0.44^{* *}$ & $0.57^{* *}$ & $-0.24^{* *}$ \\
\hline & Autumn & 0.14 & $0.19^{*}$ & $0.57^{* *}$ & $0.59^{* *}$ & 0.05 \\
\hline & Winter & 0.12 & $0.18^{*}$ & $0.58^{* *}$ & $0.72^{* *}$ & $0.22^{* *}$ \\
\hline \multirow[t]{5}{*}{ Mean maximum daily temperature $\left({ }^{\circ} \mathrm{C}\right)$} & Annual & $0.16^{*}$ & 0.13 & $0.49^{* *}$ & $0.64^{* *}$ & 0.04 \\
\hline & Spring & $0.15^{*}$ & 0.15 & $0.51^{* *}$ & $0.66^{* *}$ & 0.09 \\
\hline & Summer & 0.12 & 0.10 & $0.30^{* *}$ & $0.44^{* *}$ & -0.11 \\
\hline & Autumn & 0.14 & 0.13 & $0.47^{* *}$ & $0.59^{* *}$ & 0.02 \\
\hline & Winter & $0.16^{*}$ & $0.16^{*}$ & $0.60^{* *}$ & $0.74^{* *}$ & $0.30^{* *}$ \\
\hline \multirow[t]{5}{*}{ Mean minimum daily temperature $\left({ }^{\circ} \mathrm{C}\right)$} & Annual & 0.07 & $0.20^{* *}$ & $0.51^{* *}$ & $0.61^{* *}$ & -0.01 \\
\hline & Spring & 0.01 & 0.14 & $0.51^{* *}$ & $0.61^{* *}$ & -0.05 \\
\hline & Summer & 0.12 & $0.20^{* *}$ & $0.48^{* *}$ & $0.59^{* *}$ & -0.19 \\
\hline & Autumn & 0.00 & 0.13 & $0.47^{* *}$ & $0.58^{* *}$ & -0.03 \\
\hline & Winter & -0.01 & 0.15 & $0.41^{* *}$ & $0.52^{* *}$ & 0.04 \\
\hline \multicolumn{2}{|l|}{ Soil C:N ratio ${ }^{d}$} & - & - & $0.60^{* *}$ & $0.55^{* *}$ & $0.70^{* *}$ \\
\hline
\end{tabular}

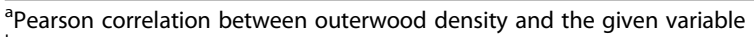

${ }^{b}$ Partial correlation between outerwood density and the given variable adjusted for age

'Partial correlation between outerwood density and the given variable adjusted for age and MAT

dSoil C:N ratio was available for 18 South Island stands

Significance levels are indicated by $*(p<0.05)$ and ${ }^{* *}(p<0.01)$

which were all obtained from stands 15 years or older in age. On the other hand, examination of the data for the South Island suggested that the effect of MAT on density follows a linear trend. Therefore, Eq. (1) which used an exponential term to account for age, and a linear term to account for temperature was used to model outerwood density as a function of age and temperature. Because of the differences in wood density between North Island stands planted before and after 1970, dummy variables were used to fit separate $a$ and $b$ parameters for
South Island, North Island post-1969, and North Island pre-1970 stands (Table 5).

A scatter plot of density adjusted to age 40 years versus $M A T$ shows strong positive relationships between breast height outerwood density and MAT for South Island stands planted before 1970, South Island stands planted after 1970, and North Island stands planted after 1970 (Fig. 2). However, pre-1970 North Island stands show little trend in density with temperature and have a much lower density for a given $M A T$ than the other 3 groups.

Table 4 Mean outerwood density by island and planting period, adjusted for age and MAT using analysis of covariance

\begin{tabular}{llll}
\hline Location & Planting year & Number of stands & Adjusted mean outerwood density $\left(\mathrm{kg} \mathrm{m}^{-3}\right)$ \\
\hline North Island & Pre-1940 & 96 & $398 \mathrm{a}$ \\
& $1940-1969$ & 73 & $413 \mathrm{a}$ \\
South Island & Post-1969 & 13 & $458 \mathrm{~b}$ \\
& Pre-1940 & 19 & $462 \mathrm{~b}$ \\
& Post-1969-1969 & 86 & $452 \mathrm{~b}$ \\
& 25 & $451 \mathrm{~b}$
\end{tabular}


Table 5 Parameter estimates for the model Eq. (1) to predict breast height outerwood density from age and MAT, with associated standard errors and tests of significance

\begin{tabular}{lllll}
\hline Parameter & Estimate & Std. error & $t$ value & $p$ value \\
\hline a, pre-1970 North Island & 381.6 & 36.3 & 10.52 & $<0.0001$ \\
a, post-1969 North Island & 217.5 & 91.9 & 2.37 & 0.018 \\
a, South Island & 195.0 & 24.5 & 7.95 & $<0.0001$ \\
b, pre-1970 North Island & 5.5 & 3.2 & 1.74 & 0.082 \\
b, post-1969 North Island & 24.0 & 7.7 & 3.10 & 0.0021 \\
b, South Island & 27.1 & 2.4 & 11.19 & $<0.0001$ \\
c & 355 & 71 & 4.98 & $<0.0001$ \\
$d$ & 0.0764 & 0.0114 & 6.70 & $<0.0001$ \\
\hline $\begin{array}{l}\text { The model explains 52.8\% of total variance and has a root mean square error } \\
\text { of } 24.8 \mathrm{~kg} \mathrm{~m}^{-3}\end{array}$
\end{tabular}

Apart from age and MAT, the variable most strongly associated with wood density based on the correlation analysis was soil $\mathrm{C}: \mathrm{N}$ ratio. Because this variable was only available for 18 South Island stands (several measurements from pre-1970 North Island stands were not used because it appeared that genetic differences overrode environmental effects in these stands), it could not be included in the main regression model. However, a regression between the residuals from Model (1) and soil $\mathrm{C}: \mathrm{N}$ ratio showed a significant trend indicating that outerwood density increases by $3.36 \mathrm{~kg} \mathrm{~m}^{-3}$ for every unit increase in soil $\mathrm{C}: \mathrm{N}$ ratio (Table 6). This regression model implies a predicted residual of zero for a soil C: $\mathrm{N}$ ratio of 22.4, with this ratio being fairly typical for forest soils in New Zealand.

\section{Influence of stand density on outerwood density}

Although the database contained only limited data from stocking trials, they were sufficient to demonstrate that wood density in New Zealand-grown Douglas-fir is not greatly influenced by stand density (Fig. 3). The slope parameter for the Eq. (3) regression model was $0.0048 \pm 0.0052$ (estimate \pm standard error) and was not significantly different from zero $\left(t_{21}=0.92, p=0.37\right)$. The model implies, for example, that an increase in stand density of 1000 stems ha $^{-1}$ would only produce an increase in wood density of $6 \pm 11 \mathrm{~kg} \mathrm{~m}^{-3}$ (95\% confidence interval). Even if the upper limit of this interval is correct, it indicates that stand density has only a minor influence on outerwood density in New Zealand Douglas-fir, at least over the range of stand densities typically used for the species.

\section{Within-stand variation in wood density between trees}

The distribution of outerwood density in individual trees across all available studies closely followed a normal distribution (Fig. 4). The coefficient of variation for outerwood density within each stand based on a single core per tree averaged $7.5 \%$ and did not vary with mean density (coefficients of variation averaged 7.8, 7.5, 7.3, and $7.6 \%$ for stands with mean wood density $<250,250$ $400,400-450$, and $>450 \mathrm{~kg} \mathrm{~m}^{-3}$ respectively).

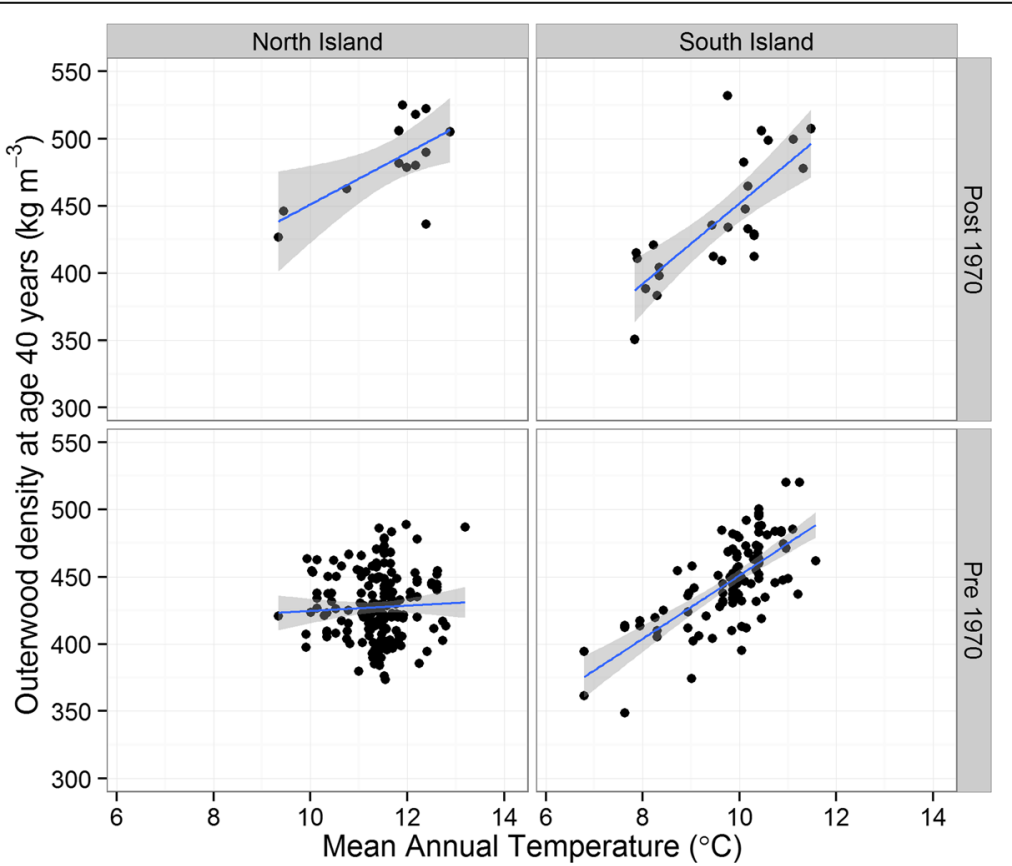

Fig. 2 Breast height outerwood density corrected to age 40 years versus MAT. Each point is the mean for a site with average number of trees per site $=36$. Blue lines were fitted using ordinal least squares regression and the grey shading indicates the $95 \%$ confidence interval 
Table 6 Parameter estimates and their standard errors and tests of significance for the regression model: (Actual - Predicted using Eq. (2)) outerwood density) $=a+b \times$ soil_C:N_ratio, based on 18 South Island sites. The model $R^{2}$ is $52.4 \%$ and it has a root mean square error of $17.6 \mathrm{~kg} \mathrm{~m}^{-3}$

\begin{tabular}{lllll}
\hline Parameter & Estimate & Std. error & $t$ Value & $p$ Value \\
\hline$a$ & -75.3 & 16.7 & -4.51 & 0.0004 \\
$b$ & 3.36 & 0.80 & 4.20 & 0.0007 \\
\hline
\end{tabular}

The mean coefficient of variation of $7.5 \%$ can be considered to slightly overstate the true variation among trees as it is based on a single small core sample per tree, and therefore includes an element of within-tree variation. A variance component analysis was applied to the 20 stands where two cores were taken per tree (from opposite sides of the stem) to estimate the between- and within-tree variance components which were 997 and 177 respectively. These results show that inter-tree variation is large relative to within-tree variation in a typical stand. However, they also show that the true inter-tree variation expressed as a standard deviation would be $8 \%$ lower than the variation measured using single cores. This indicates that for modelling purposes, an inter-tree coefficient of variation of $6.9 \%$ (rather than $7.5 \%$ ) is appropriate. This value is, therefore, used in the Forecaster simulation system which stochastically varies wood density among stems within a simulation, thus providing a realistic level of variation in wood density among logs at harvest.

The pooled within-stand correlation coefficient between wood density and tree diameter was -0.089 indicating a very weak, although statistically significant $(p=0.0095)$ negative relationship within a typical stand. The mean

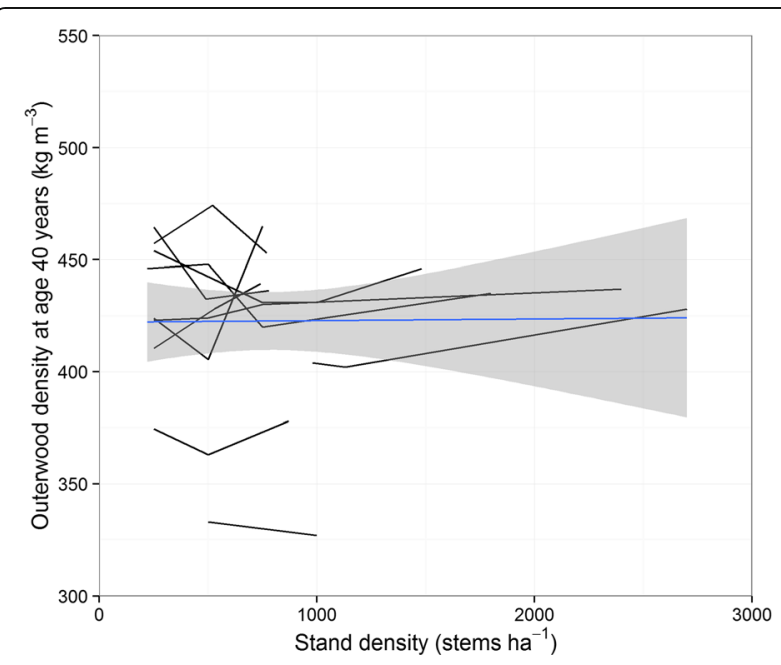

Fig. 3 Relationship between breast height outerwood density and stand density. Each solid line represents data from a separate stocking trial. The blue line shows the overall regression model for an average site and the grey shading indicates the 95\% confidence interval

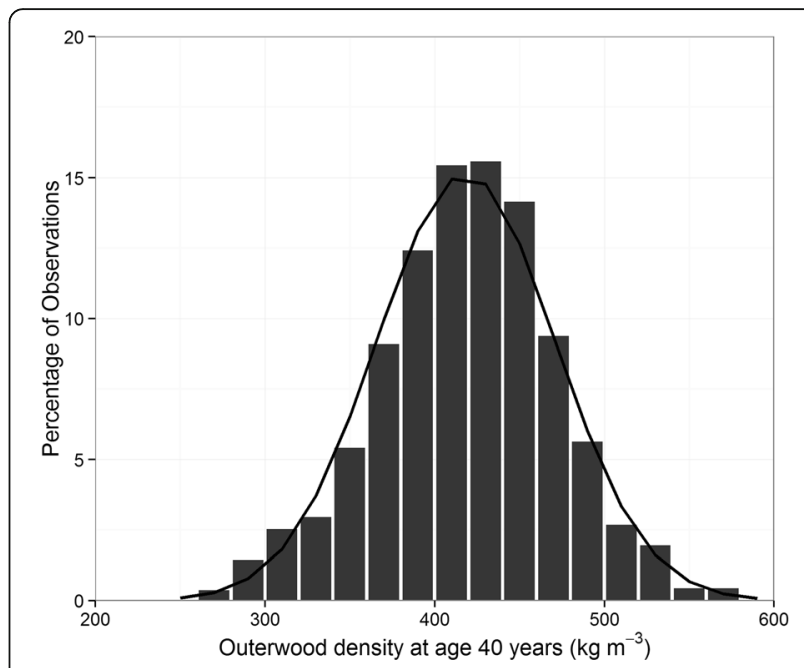

Fig. 4 Distribution of outerwood density in individual trees with fitted normal distribution

DBH of stands used in this analysis was $392 \mathrm{~mm}$ and the mean coefficient of variation was $17 \%$. Because the relationship between wood density and stem diameter is so weak, no attempt is made to adjust wood density for tree diameter within a stand in the Forecaster simulation system.

\section{Within-stem radial pattern of wood density}

A common radial pattern was observed in the ring-level breast-height density data available from 47 stands. Starting at the pith, wood density decreases over the first seven rings, and then begins a gradual increase after ring ten, eventually stabilising beyond about ring 30 (Fig. 5). Variation among stands increases over the first ten rings, and then stabilises. This behaviour was well modelled by Eq. (4) which explained $81 \%$ of the variation in breastheight density in the dataset. This could be partitioned into variation among sites which explained $62 \%$ of the variation and the pith to bark trend described by the model which explained a further 19\%. Parameter estimates are given in Table 7.

\section{Within-stem longitudinal pattern of wood density}

Equation (5) was used to model the within-stem longitudinal pattern of wood density (Fig. 6). This model explained $79 \%$ of the variation in disc density in the dataset which could be partitioned into variation among sites explaining $31 \%$ of total variation, among trees within stands explaining 37\%, and the longitudinal trend in density which explained a further $11 \%$. Parameter estimates are given in Table 8 .

\section{Application of the model}

The wood density models described above, implemented within the Forecaster growth and yield simulator, were used to predict the distribution of densities of logs 


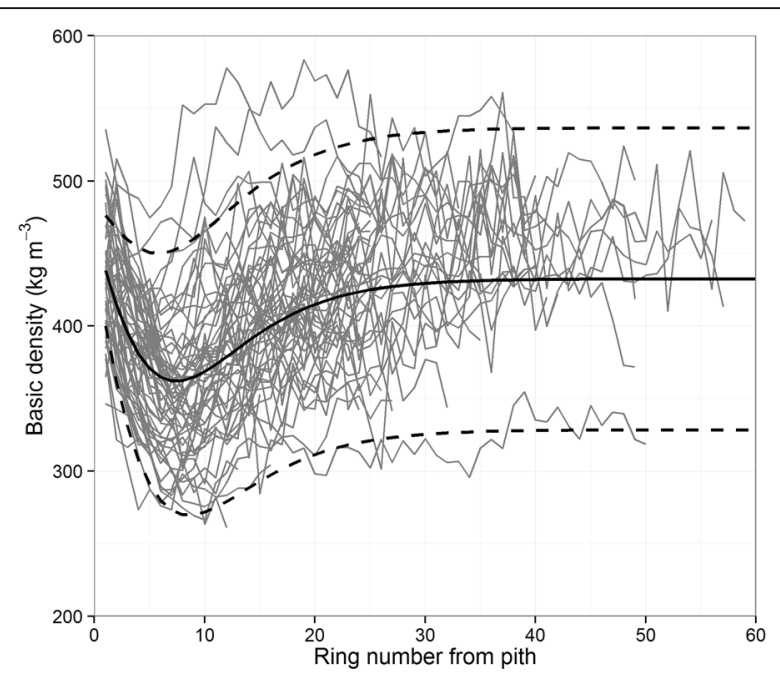

Fig. 5 Pith-to-bark radial pattern of breast height density by ring. Fine lines show densities for individual stands. The solid line shows the density predicted by Model (3) for an average site $(L=0)$. The dashed lines for sites at the 5th and 95th percentiles (lower and upper lines, $L=-104$ and $L=+104$, respectively)

harvested from stands grown on three different sites. Predicted log average density followed the expected pattern given the differences in mean annual air temperature between the sites (Fig. 7). At age 40 years, in the stand growing on the warmest site in the North Island, average wood density for the butt $\log$ was $467 \mathrm{~kg}$ $\mathrm{m}^{-3}$ compared with $376 \mathrm{~kg} \mathrm{~m}^{-3}$ for the stand growing in the southern South Island. The stand in the upper South Island was intermediate with the butt $\log$ averaging $426 \mathrm{~kg} \mathrm{~m}^{-3}$ in density at the same age. Whole-log wood density decreased with increasing log height up the stem. At stand age of 40 years, the fourth $\log$ was $31 \mathrm{~kg}$ $\mathrm{m}^{-3}$ lower in density than the butt $\log$ in the North Island site, but only $8-18 \mathrm{~kg} \mathrm{~m}^{-3}$ lower in the South Island sites. Rotation length had only a small effect; for

Table 7 Parameter estimates and their standard errors and tests of significance for the model Eq. (4) to predict the radial variation in wood density

\begin{tabular}{lllll}
\hline Parameter & Estimate & Std. error & $t$ Value & $p$ Value \\
\hline$a$ & 432.6 & 6.5 & 66.23 & $<0.0001$ \\
$b$ & 1.22 & 0.20 & 6.11 & $<0.0001$ \\
$c$ & 0.0235 & 0.0062 & 3.81 & 0.0003 \\
$d$ & 0.0125 & 0.0026 & 4.82 & $<0.0001$ \\
$f$ & 0.221 & 0.017 & 13.21 & $<0.0001$ \\
$g$ & 0.814 & 0.089 & 9.24 & $<0.0001$ \\
$h$ & 0.258 & 0.040 & 6.47 & $<0.0001$ \\
$\sigma_{\text {stand }}^{2}$ & 702 & 24 & 28.78 & $<0.0001$ \\
$\sigma_{e}^{2}$ & 2155 & 347 & 6.22 & $<0.0001$ \\
\hline Estimates of the & betwen & &
\end{tabular}

Estimates of the between stand variance $\left(\sigma_{s t a n d}^{2}\right)$ and within-radial error term variance $\left(\sigma_{e}^{2}\right)$ for the local parameter $L$ are also given

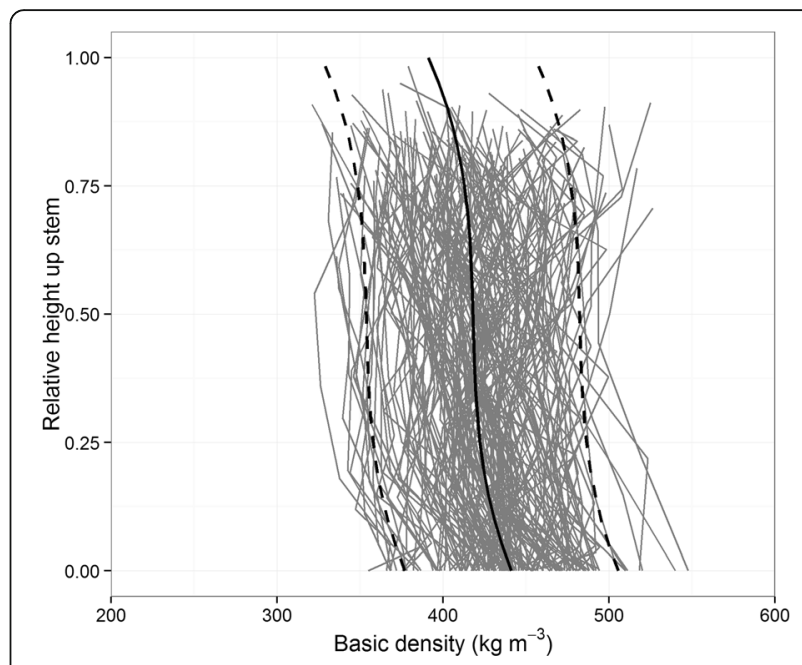

Fig. 6 Longitudinal pattern of disc density within stem by relative height. Fine lines show densities for individual trees. The solid line shows the density predicted by Model (4) for an average site $(L=0)$. The dashed lines for sites at the 5th and 95th percentiles (lower and upper lines, $L=-64$ and $L=+64$, respectively)

an equivalent $\log$ height, there was an increase in $\log$ average density of $2-4 \mathrm{~kg} \mathrm{~m}^{-3}$ for each 5 year increase in rotation length. Finally, the difference between the two silvicultural regimes was minimal $\left(\sim 1-3 \mathrm{~kg} \mathrm{~m}^{-3}\right)$.

\section{Discussion}

This study quantifies the extent of variation in wood density of New Zealand Douglas-fir among sites, among trees within a stand as well as radially and longitudinally within trees. The average outerwood density of the New Zealand grown Douglas-fir in this study was $427 \mathrm{~kg} \mathrm{~m}^{-3}$, lower than is typical for the species growing in its native range. For example, a survey of coast Douglas-fir across 45 sites found the density of wood formed at age 50 years to average $479 \mathrm{~kg} \mathrm{~m}^{-3}$ (Lassen and Okkonen 1969). There are likely to be a combination of reasons for the lower densities of New Zealand Douglas-fir including

Table 8 Parameter estimates and their standard errors and tests of significance for the model Eq. (5) to predict the longitudinal variation in wood density

\begin{tabular}{lllll}
\hline Parameter & Estimate & Std. error & $t$ Value & $p$ Value \\
\hline$a$ & 436.6 & 6.0 & 73.2 & $<0.0001$ \\
$b$ & -126.4 & 15.2 & -8.30 & $<0.0001$ \\
$c$ & 243.7 & 44.0 & 5.54 & $<0.0001$ \\
$d$ & -167.5 & 34.1 & -4.92 & $<0.0001$ \\
$\sigma_{\text {stand }}^{2}$ & 538.0 & 215.5 & 2.50 & 0.0063 \\
$\sigma_{\text {tree }(\text { stand })}^{2}$ & 640.0 & 79.3 & 8.07 & $<0.0001$ \\
$\sigma_{e}^{2}$ & 355.1 & 16.0 & 22.23 & $<0.0001$ \\
\hline $\begin{array}{l}\text { Estimates of the variance between stands }\left(\sigma_{\text {stand }}^{2}\right), \text { trees }\left(\sigma_{\text {tree }(\operatorname{stan} d)}^{2}\right), \text { and within } \\
\text { trees }\left(\sigma_{e}^{2}\right) \text { for the local parameter } L \text { are also given }\end{array}$
\end{tabular}





Fig. 7 Predicted values of whole-log average density for (a) stands grown at three contrasting sites, (b) under different silvicultural regimes (combinations of initial and post-thinning stand density), (c) for four different rotation lengths, and (d) at different heights up the stem (5-m height classes)

greater fertility and correspondingly faster growth rates, younger measurement ages, and lower stand densities. Also, a considerable proportion of the data in this study were from North Island stands planted before 1970 which are of significantly lower wood density possibly because of their genetics; the North Island stands planted after 1970 averaged $462 \mathrm{~kg} \mathrm{~m}^{-3}$, which is much closer to the North American average.

Wood density was found to be strongly influenced by air temperature, especially winter temperature. Similar positive relationships between wood density and temperature have been found for Douglas-fir in the Pacific Northwest of North America (Filipescu et al. 2014), and also for both Douglas-fir and radiata pine in New Zealand (Cown 1974, 1999; Harris 1985; Palmer et al. 2013). This effect has been explained as being caused by warmer temperatures producing an earlier transition in spring from earlywood to latewood, allowing a longer period of higher density latewood production (Kantavichai et al. 2010a). In this study, South Island-grown Douglas-fir outerwood density was shown to increase by $25.4 \mathrm{~kg} \mathrm{~m}^{-3}$, and North Island stands planted after 1969 by $19.2 \mathrm{~kg} \mathrm{~m}^{-3}$, for every $1{ }^{\circ} \mathrm{C}$ increase in $M A T$. This is even greater than the increase of $15.9 \mathrm{~kg} \mathrm{~m}^{-3}$ per $1{ }^{\circ} \mathrm{C}$ increase in $M A T$ for New Zealand-grown radiata pine (Beets et al. 2007). The majority of New Zealand's Douglas-fir resource is now grown on cooler, often more snow-prone sites located at higher elevations in the South Island. Stands on these sites will have lower density compared to stands grown on warmer sites in the North Island.

The lack of a strong relationship between wood density and MAT for North Islands stands planted prior to
1970 is difficult to explain. However, previous studies in New Zealand have shown large differences in wood density between different Douglas-fir provenances (Lausberg et al. 1995) and it is possible that environmental effects may have been masked by genetic differences between stands. This study shows that North Island stands planted before 1970 were of much lower wood density than those planted after this date. For example, the database contained 115 pre-1970 stands and six post-1970 stands within Kaingaroa Forest (the largest North Island forest), with the stands planted in the earlier period having a mean outerwood density $55 \mathrm{~kg} \mathrm{~m}^{-3}$ lower than those planted in the latter period after adjusting for stand age. The reason for this dissimilarity is not known, but it is possible that it is due to differences in the genotypes planted in each period.

Other climate variables such as rainfall were not significantly associated with wood density after adjusting for stand age and temperature. A negative association between Douglas-fir wood density and rainfall has been observed in the Pacific Northwest of North America (Filipescu et al. 2014), although summer moisture deficit has been shown to negatively affect Douglas-fir ringlevel wood density on a drought-prone site (Kantavichai et al. 2010a). It is possible that rainfall on typical New Zealand Douglas-fir sites is above any threshold where it might affect wood density or is sufficiently welldistributed throughout the growing season that severe seasonal moisture deficits rarely occur.

Previous work in New Zealand-grown radiata pine has shown that there is a negative relationship between wood density and soil fertility (Cown and McConchie 1981), specifically the ratio of $C$ to $N$ (Beets et al. 2007). 
Similar results have be noted for Douglas-fir with, for example, wood density decreasing after application of biosolids to the soil (Kantavichai et al. 2010a). In our dataset, soil $\mathrm{C}$ and $\mathrm{N}$ measurements were available for a subset of 18 South Island stands, and these stands displayed a reduction in wood density with soil fertility. After adjusting for age and temperature, wood density increased by $3.36 \mathrm{~kg} \mathrm{~m}^{-3}$ for every unit increase in C:N ratio. This is a comparable although slightly lower value than that found for radiata pine of 4.1 (Beets et al. 2007). (Note also that the radiata pine model used the adjusted ratio $\mathrm{C} /(\mathrm{N}-0.014)$; using this adjusted ratio, the coefficient for Douglas-fir is 2.96.) Interpolated spatial surfaces of the soil carbon to nitrogen ratio have been developed (Watt and Palmer 2012) and these could potentially be used to predict site-level differences.

The lack of response of wood density to differences in tree spacing was somewhat unexpected given that many studies across of a range of conifer species have shown that wood density is generally lower in wider-spaced stands (e.g. Brazier 1970; Clark III et al. 2008; Savill and Sandels 1983; Watt et al. 2011). Our study focused on breast height outerwood density and it must be remembered that the wood surrounding the pith has lower density than the outerwood. Therefore, increased initial growth rates, while not necessarily causing a decrease in individual ring wood density, will likely result in an increase in the proportion of corewood and a lower whole-stem average wood density. The observed lack of a relationship between wood density and tree spacing does not mean that the stiffness of timber is not influenced by stand density. Stand density has been shown to have a strong effect on branch size, which is an important determinant of timber stiffness (Auty et al. 2012; Hein et al. 2008; Maguire et al. 1999; Whiteside et al. 1976). In addition, numerous studies have found positive associations between stand density and wood stiffness in a range of species (Lasserre et al. 2009; Moore et al. 2009; Watt et al. 2011; Zhang et al. 2006). This includes a recent study in Germany which showed that higher stiffness Douglas-fir timber is obtained from stands planted at higher initial densities (Rais et al. 2014). Therefore, this result should be interpreted with caution and future work is required in New Zealand to establish robust relationships between timber stiffness values, wood density and knot size incorporating the full range of sites and provenances.

Given that radiata pine is the predominant commercial species grown in New Zealand, and is, therefore, familiar to forest managers and wood processors, it is both useful and informative to compare the wood properties of the two species. The average outerwood density value for Douglas-fir observed in this study $\left(429 \mathrm{~kg} \mathrm{~m}^{-3}\right)$ was almost the same as the average value of $439 \mathrm{~kg} \mathrm{~m}^{-3}$ obtained in a similar study on radiata pine (Palmer et al. 2013). Both species exhibit strong genetic influences on wood density, and as shown in this study, the environmental effects of temperature and soil fertility are very similar for both species. Within-site variation between trees is also very similar, with the average coefficient of variation in outerwood density of $7.5 \%$ observed in this study almost identical to the value of $7.4 \%$ in a similar study on radiata pine (Kimberley et al. 2015). The lack of relationship between the coefficient of variation and the mean level of density is similar to the pattern observed for radiata pine (Cown 1999). Neither species exhibited a strong relationship between wood density and tree diameter within a stand.

However, within-stem patterns in wood density vary considerably between the two species. Although both species show a tendency for wood density to increase radially from the centre of the stem, and for discs or logs to decrease in wood density with height in the stem, the effects are far more pronounced in radiata pine than Douglas-fir. Wood density typically increases by about $110 \mathrm{~kg} \mathrm{~m}^{-3}$ from rings 1 to 30 in radiata pine (Kimberley et al. 2015), but only by about $65 \mathrm{~kg} \mathrm{~m}^{-3}$ between its lowest level at ring 7 to ring 30 in Douglas-fir. Disc density at $80 \%$ tree height is about $38 \mathrm{~kg} \mathrm{~m}^{-3}$ less than at the base of the stem in Douglas-fir, while in radiata pine the difference is about $70 \mathrm{~kg} \mathrm{~m}^{-3}$ (Kimberley et al. 2015). From a practical perspective, this means that the $\log$ and stem average density for a given breast density value will be higher in Douglas-fir than in radiata pine.

The density models described in this paper have been implemented in the Forecaster stand simulation system (West et al. 2013), where they can be used in conjunction with growth models and stem volume and taper equations to estimate intra-stem wood density profiles and density variation for log assortments. The simulations undertaken in this paper show that differences in average density of logs in New Zealand grown Douglasfir are mostly the result of site level differences in mean annual air temperature. There is little difference in density between the two silvicultural regimes, which was not unexpected given the lack of a relationship between outerwood density and stand stocking. Similarly, the relatively small influence of rotation length on whole log density was not unexpected given the magnitude of radial and longitudinal trends in density, particular compared with those found in radiata pine (Kimberley et al. 2015). Given that wood density in Douglas-fir does not appear to be under a high degree of silvicultural control, it is more likely that forest managers would use the model to determine whether a stand growing on a particular site would yield logs capable of meeting certain wood density levels. The model currently does not account for genetic differences in wood density. A 
similar radiata pine wood density model can predict the effects of genetic differences in wood density using the GF Plus Wood Density Rating assigned to many commercial radiata pine seedlots (Kimberley et al. 2016). A similar rating system for Douglas-fir seedlots does not currently exist, although if such a system was developed, it could be readily implemented within the wood density model (see Appendix). However, it is possible to adjust for genetic effects manually when using the model. For example, if a seedlot is believed to produce wood density $50 \mathrm{~kg} \mathrm{~m}^{-3}$ higher than an average genotype, predictions from Eq. (1) could be adjusted by this amount enabling the model to produce realistic wood density predictions for that seedlot.

There are several priority areas for further work to develop, refine and validate the models presented in this paper. Because the wood properties models are a series of component models that have also been coupled to models that predict tree growth, taper and volume, error propagation is likely to be important. This is a common issue in forest modelling, particularly when several models are linked together or when data obtained from field sampling are used as input into predictive models (Weiskittel et al. 2011). Because the standard errors of the parameter estimates for the wood property models are available along with the root mean square errors for these models, techniques such as Monte Carlo simulations can be used to estimate the magnitude of the prediction error when these models are combined. The error associated with log level density predictions could also be estimated provided similar information can be obtained for the models describing tree growth, volume and taper. Further validation of the models should be undertaken to ensure that predictions are robust for the range of site conditions under which Douglas-fir is grown in New Zealand. A priority would be to further examine the relationship between stand density and wood density.

\section{Conclusions}

The study has quantified the sources and magnitude of variation in Douglas-fir wood density at a range of scales based on analyses of a comprehensive dataset collected over a 50 year period. This has highlighted the relative contributions of site and silviculture, with most of the variation in wood density among trees due to site level differences in mean annual air temperature. The models developed to explain these trends in wood density have been coupled together and linked to a growth and yield simulator which enables forest managers to estimate the impact of different factors, primarily site, on the wood density distribution of $\log$ product assortments. By combining this information with branch characteristics, the impacts on the performance of structural timber can be inferred.

\section{Appendix}

\section{Incorporation of the wood density models into the forecaster growth and yield simulator}

Forecaster uses growth models to simulate the development with age of a list of stems representing a forest stand. At the required clearfell age, or for production thinning, Forecaster predicts the volumes and other characteristics of logs cut from the felled stems. It is also capable of predicting quality attributes for each log such as branch size and wood properties. To simulate properties such as wood density, Forecaster requires models for predicting the property within a stem in terms of, for example, height and ring number, or height and tree age. The Douglas-fir wood density models described in this paper as implemented in Forecaster will operate using the following steps:

1. Predict stand mean breast height outerwood density for age 40 years $\left(D_{40 o w}\right)$. This prediction can be obtained using either an environmental model based on MAT and soil C:N ratio, or from a user-supplied measurement of outerwood density $\left(D_{\text {ow }}\right)$ (e.g., from cores taken from sample trees). Given the variability between sites and because of genetic variation, it will always be more accurate to use a measurement of outerwood density taken from the stand of interest rather than to rely on the environmental model. If an outerwood density measurement is available, it is adjusted to age 40 years using:

$$
D_{40 o w}=D_{o w}-331[\exp (-0.0731 \times 40)-\exp (-0.0731 \times A g e)]
$$

The environmental model is based on Eq. (1) evaluated at age 40 years for South Island and post-1969 North Island stands, i.e.:

$$
\begin{aligned}
& \text { South Island : } D_{40 \mathrm{ow}}=197.2+25.4 \times M A T \\
& +(\text { SoilCN-22) } \times 3.36 \\
& \text { North Island : } D_{40 \mathrm{ow}}=259.2+19.2 \times M A T \\
& +(\text { SoilCN-22) } \times 3.36
\end{aligned}
$$

The soil C:N ratio adjustment used in the environmental model uses an assumption that stands in the database used to develop the MAT model had an average soil C:N ratio of 22. Note that if soil C:N ratio is not known, a default value of 22 will be used.

2. Predict mean breast height wood densities $\left(D_{\text {ring }}\right)$ by ring number from pith $(R)$ using the following equations based on Eq. (4) assuming that density of the outer $50 \mathrm{~mm}$ of a breast height increment core is centred on ring 29 from pith. This assumption is used because, (i) it typically takes 3 years for a planted seedling to reach 
$1.4 \mathrm{~m}$ height, (ii) a typical breast height outerwood core at age 40 years contains 15 rings (rings 22-37), and (iii) although this implies a central location at ring 29 , it is more correct to use ring 28 because inner rings are wider than outer rings.

$$
\begin{aligned}
& L=\left(D_{40 \text { ow }}-432.4\right) / 0.9993 \\
& \begin{aligned}
D_{\text {ring }}=432.4 & +(1.22-R) /(0.0235+1.25 \\
& \times \exp (0.221 \times R)) \\
& +(1-0.814 \times \exp (-0.251 \times R)) \times L
\end{aligned}
\end{aligned}
$$

These predictions are used to predict disc density at breast height $\left(D_{b h}\right)$ for any required age based on area weighted averages using ring widths predicted by the growth model.

One of the shortcomings of the current model is that it does not account for genetic differences in wood density. Currently, Douglas-fir seedlots sold in New Zealand do not have a wood density rating unlike commercial radiata pine seedlots which are often assigned GF Plus density ratings. However, if a Douglas-fir seedlot were known to produce trees of higher or lower than average $D_{40 o w}$, this effect could be incorporated into the density predictions by using the adjusted $D_{40 o w}$ when calculating $L$ in Eq. (A4).

3. Predict disc densities $\left(D_{\text {disc }}\right)$ at suitable intervals up each stem as a function of breast height disc density $\left(D_{b h}\right)$, disc height $\left(H_{\text {disc }}\right)$, and total tree height $(H)$, allowing volume-weighted densities of logs cut from each stem to be calculated. The following equations based on Eq. (5) are used:

$$
\begin{aligned}
L=D_{b h}- & (436.6-126.4 \times 1.4 / H+243.7 \\
& \left.\times(1.4 / H)^{2}-167.5 \times(1.4 / H)^{3}\right) \\
D_{\text {disc }}= & +436.6-126.4 \times H_{\text {disc }} / H+243.7 \\
& \times\left(H_{\text {disc }} / H\right)^{2}-167.5 \times\left(H_{\text {disc }} / H\right)^{3}
\end{aligned}
$$

4. The above steps allow prediction of wood densities of logs for an average tree in the stand. To simulate a realistic variation about this average, Forecaster uses a stochastic approach, generating a normally distributed random variate with mean one and coefficient of variation $6.9 \%$ for each stem, and multiplying all predicted $\log$ densities for the stem by this variate.

\section{Acknowledgements}

Funding for this study was provided from the Forest Growers Levy, Future Forests Research Ltd. and Scion. Ernslaw One Ltd., City Forests Ltd. and Blakely Pacific provided support for the collection of additional data. We are particularly grateful to Mark Dean and Don McConchie for their assistance with field data collection. Christine Dodunski entered some of the historical data into the database and along with Richard Moberly assisted with the gravimetric density assessments. We would like to thank numerous current and former colleagues who collected density samples over many years. More recent outerwood density data were collected by Stuart Kennedy, Stephen Pearce and Peter Beets. Brian Clement and Jeremy Snook incorporated the wood density model into the Forecaster growth and yield prediction system. We would also like to thank two anonymous reviewers for their helpful comments on an earlier version of this manuscript.

\section{Authors' contributions}

MOK developed the modelling approach, undertook the data analysis and contributed to writing the manuscript. DJC and RBMcK collected and assembled most of the wood density data, contributed to the interpretation of the results and writing of the manuscript. JRM contributed to writing the manuscript and undertook the Forecaster analysis. All authors read and approved the final version of the manuscript.

\section{Competing interests}

The authors declare that they have no competing interests.

\section{Publisher's Note}

Springer Nature remains neutral with regard to jurisdictional claims in published maps and institutional affiliations.

Received: 14 August 2016 Accepted: 19 July 2017

Published online: 11 August 2017

\section{References}

Antonova, G. F., \& Stasova, V. V. (1997). Effects of environmental factors on wood formation in larch (Larix sibirica Ldb.) stems. Trees, 11, 462-468.

Auty, D., Weiskittel, A. R., Achim, A., Moore, J. R., \& Gardiner, B. A. (2012). Influence of early re-spacing on Sitka spruce branch structure. Annals of Forest Science, 69, 93-104.

Barrett, J. D., \& Kellogg, R. M. (1991). Bending strength and stiffness of secondgrowth Douglas-fir dimension lumber. Forest Products Journal, 41(10), 35-43.

Beets, P. N., Kimberley, M. O., \& McKinley, R. B. (2007). Predicting wood density of Pinus radiata annual growth increments. New Zealand Journal of Forestry Science, 37(2), 241-266.

Brazier, J. D. (1970). The effect of spacing on the wood density and wood yields of Sitka spruce. Supplement to Forestry, 22-28.

Clark III, A., Jordan, L., Schimleck, L., \& Daniels, R. F. (2008). Effect of initial planting spacing on wood properties of unthinned loblolly pine at age 21. Forest Products Journal, 58(10), 78-83.

Cown, D. J. (1974). Wood density of radiata pine: Its variation and manipulation. New Zealand Journal of Forestry, 19(1), 84-92.

Cown, D. J. (1999). New Zealand pine and Douglas-fir: Suitability for processing. (FRI Bulletin 216). Rotorua, New Zealand: New Zealand Forest Research Institute.

Cown, D. J., \& Clement, B. C. (1983). A wood densitometer using direct scanning with X-rays. Wood Science and Technology, 17(2), 91-99.

Cown, D. J., \& McConchie, D. L. (1981). Effects of thinning and fertiliser application on wood properties of Pinus radiata. New Zealand Journal of Forestry Science, 11, 79-91.

Cown, D. J., \& Parker, M. L. (1979). Densitometric analysis of wood from five Douglas-fir provenances. Silvae Genetica, 28(2/3), 48-53.

Filipescu, C. N., Lowell, E. C., Koppenaal, R., \& Mitchell, A. K. (2014). Modeling regional and climatic variation of wood density and ring width in intensively managed Douglas-fir. Canadian Journal of Forest Research, 44(3), 220-229.

Grace, J. C., Brownlie, R. K., \& Kennedy, S. G. (2015). The influence of initial and post-thinning stand density on Douglas-fir branch diameter at two sites in New Zealand. New Zealand Journal of Forestry Science, 45:14.

Harris, J. M. (1966). A survey of the wood density of Douglas-fir grown in New Zealand. (Forest Products Report 194). Rotorua: New Zealand Forest Service, Forest research institute.

Harris, J. M. (1967). Wood density as a criterion for thinning Douglas fir. New Zealand Journal of Forestry, 12(1), 54-62.

Harris, J. M. (1978). Intrinsic wood properties of Douglas fir and how they can be modified. In: Forest Research Institute, Symposium No. 15: A review of Douglas-fir in New Zealand. New Zealand Forest Research Institute, Rotorua, New Zealand. Pp. 235-239.

Harris, J. M. (1985). Effects of site and silviculture on wood density of Douglas fir grown in Canterbury conservancy. New Zealand Journal of Forestry, 30(1), 121-132.

Hayes, J., \& Andersen, C. (2007). The Scion permanent sample plot (PSP) database system. New Zealand Journal of Forestry, 52(1), 31-33. 
Hein, S., Weiskittel, A. R., \& Kohnle, U. (2008). Effect of wide spacing on tree growth, branch and sapwood properties of young Douglas-fir [Pseudotsuga menziesii (Mirb.) Franco] in south-western Germany. European Journal of Forest Research, 127, 481-493.

Jordan, L., Clark, A., Schimleck, L., Hall, D. B., \& Daniels, R. F. (2008). Regional variation in wood specific gravity of planted loblolly pine in the United States. Canadian Journal of Forest Research, 38(4), 698-710.

Jozsa, L. A., \& Brix, H. (1989). The effects of fertilization and thinning on wood quality of a 24-year-old Douglas-fir stand. Canadian Journal of Forest Research, 19(9), 1137-1145.

Kantavichai, R., Briggs, D., \& Turnblom, E. (2010a). Modeling effects of soil, climate, and silviculture on growth ring specific gravity of Douglas-fir on a droughtprone site in western Washington. Forest Ecology and Management, 259(6), 1085-1092.

Kantavichai, R., Briggs, D. G., \& Turnblom, E. C. (2010b). Effect of thinning, fertilization with biosolids, and weather on interannual ring specific gravity and carbon accumulation of a 55-year-old Douglas-fir stand in western Washington. Canadian Journal of Forest Research, 40(1), 72-85.

Kellog, R. M. (Ed.). (1989). Second growth Douglas-fir: Its management and conversion for value (Special publication no. SP-32). Vancouver, B.C.: Forintek Canada Corporation.

Kimberley, M. O., Cown, D. J., McKinley, R. B., Moore, J. R., \& Dowling, L. J. (2015). Modelling variation in wood density within and among trees in stands of New Zealand-grown radiata pine. New Zealand Journal of Forest Science, 45: (22), 1-13.

Kimberley, M. O., Moore, J. R., \& Dungey, H. S. (2016). Modelling the effects of genetic improvement on radiata pine wood density. New Zealand Journal of Forestry Science, 46:8, 1-8

Knowles, R. L., Hansen, L. W., Downes, G., Lee, J. R., Barr, A. B., Roper, J. G., \& Gaunt, D. J. (2003). Modelling within-tree and between-tree variation in Douglas-fir wood and lumber properties. Abstract in Proceedings, IUFRO All Division 5 Conference, "Forest Products Research - Providing for Sustainable Choices", Rotorua, NZ, 11-15 March 2003, 94.

Lassen, L. E., \& Okkonen, E. A. (1969). Effect of rainfall and elevation on specific gravity of coast Douglas-fir. Wood and Fiber Science, 1, 227-235.

Lasserre, J. P., Mason, E. G., Watt, M. S., \& Moore, J. R. (2009). Influence of initial planting spacing and genotype on microfibril angle, wood density, fibre properties and modulus of elasticity in Pinus radiata D.Don corewood. Forest Ecology and Management, 258(9), 1924-1931.

Lausberg, M. (1996). Wood density variation in Douglas-fir provenances in New Zealand. Proceedings of Wood Quality Workshop '95, FRI Bulletin No. 201, New Zealand Forest Research Institute, Rotorua, New Zealand. Pp. 64-71.

Lausberg, M. J. F., Cown, D. J., McConchie, D. L., \& Skipwith, J. H. (1995). Variation in some wood properties of Pseudotsuga menziesii provenances grown in New Zealand. New Zealand Journal of Forestry Science, 25, 133-146.

Maclaren, J. P. (2009). Douglas-fir manual. Forest Research Bulletin 237. New Zealand Forest Research Institute Limited, Rotorua, New Zealand.

Maeglin, R. R., \& Wahlgren, H. E. (1972). Western Wood Density Survey Report No. 2. Research Paper FPL 183, USDA Forest Service, Forest Products Laboratory, Madison, Wisconsin. 24pp.

Maguire, D. A., Johnston, S. R., \& Cahill, J. (1999). Predicting branch diameters on second-growth Douglas-fir from tree-level descriptors. Canadian Journal of Forest Research, 29(12), 1829-1840.

Maguire, D. A., Kershaw Jr., J. A., \& Hann, D. W. (1991). Predicting the effects of silvicultural regime on branch size and crown wood core in Douglas-fir Forest Science, 37, 1409-1428.

Ministry for Primary Industries. (2014). National Exotic Forest Description as at 1 April 2014. Wellington: Ministry for Primary Industries.

Moore, J., Achim, A., Lyon, A., Mochan, S., \& Gardiner, B. (2009). Effects of early respacing on the physical and mechanical properties of Sitka spruce structural timber. Forest Ecology and Management, 258(7), 1174-1180.

Palmer, D. J., Kimberley, M. O., Cown, D. J., \& McKinley, R. B. (2013). Assessing prediction accuracy in a regression kriging surface of Pinus radiata outerwood density across New Zealand. Forest Ecology and Management, 308, 9-16.

Pojar, J., \& MacKinnon, A. (Eds.). (1994). Plants of the Pacific Northwest Coast Washington. Oregon, British Columbia and Alaska: Lone Pine Publishing.

Rais, A., Poschenrieder, W., Pretzsch, H., \& van de Kuilen, J. W. G. (2014). Influence of initial plant density on sawn timber properties for Douglas-fir (Pseudotsuga menziesii (Mirb.) Franco). Annals of Forest Science, 71(5), 617-626.

SAS Institute Inc. (2011). Base SAS ${ }^{\circledR} 9.3$ Procedures Guide. Cary, NC: SAS Institute Inc.
Savill, P. S., \& Sandels, A. J. (1983). The influence of early respacing on the wood density of Sitka spruce. Forestry, 65(2), 109-120.

Smith, D. M. (1954). Maximum moisture content method for determining specific gravity of small wood samples. (Report 2014). Madison, Wl: United States Department of Agriculture, Forest Service, Forest Products Laboratory.

Stoehr, M. U., Ukrainetz, N. K., Hayton, L. K., \& Yanchuk, A. D. (2009). Current and future trends in juvenile wood density for coastal Douglas-fir. Canadian Journal of Forest Research, 39(7), 1415-1419.

Stone, J. K., Hood, I. A., Watt, M. S., \& Kerrigan, J. L. (2007). Distribution of Swiss needle cast in New Zealand in relation to winter temperature. Australasian Plant Pathology, 36(5), 445.

Tustin, J. R., \& Wilcox, M. D. (1978). The relative importance of branch size and wood density to the quality of Douglas fir framing timber. In: Forest Research Institute, Symposium No. 15: A review of Douglas-fir in New Zealand. New Zealand Forest Research Institute, Rotorua, New Zealand. Pp. 267-272.

USDA (1965). Western Wood Density Survey Report No. 1. Research Paper FPL-27. USDA Forest Service, Forest Products Laboratory, Madison, Wisconsin. 60pp.

Vargas-Hernandez, J., \& Adams, W. T. (1994). Genetic relationships between wood density components and cambial growth rhythm in young coastal Douglasfir. Canadian Journal of Forest Research, 24(9), 1871-1876.

Vikram, V., Cherry, M. L., Briggs, D., Cress, D. W., Evans, R., \& Howe, G. T. (2011) Stiffness of douglas-fir lumber: Effects of wood properties and genetics. Canadian Journal of Forest Research, 41(6), 1160-1173.

Watt, M. S., \& Palmer, D. J. (2012). Use of regression kriging to develop a carbon: nitrogen ratio surface for New Zealand. Geoderma, 183-184, 49-57.

Watt, M. S., Zoric, B., Kimberley, M. O., \& Harrington, J. (2011). Influence of stocking on radial and longitudinal variation in modulus of elasticity, microfibril angle, and density in a 24-year-old Pinus radiata thinning trial. Canadian Journal of Forest Research, 41(7), 1422-1431.

Weiskittel, A. R., Hann, D. W., Kershaw Jr., J. A., \& Vanclay, J. K. (2011). Forest Growth and Yield Modeling. Chichester, UK: John Wiley \& Sons, Ltd.

Wellwood, R. W. (1952). The effect of several variables on the specific gravity of second-growth Douglas-fir. Forestry Chronicle, 28(3), 34-42. doi:10.5558/ tfc28034-28033.

West, G. G., Moore, J. R., Shula, R. G., Harrington, J. J., Snook, J., Gordon, J. A., \& Riordan, M. P. (2013). Forest management DSS development in New Zealand (pp. 153-163). Slovakia: Paper presented at the Implementation of DSS Tools into the Forestry Practice, Technical University of Zvolen.

Whiteside, I. D. (1978). Machine stress grading studies and grading rules for Douglas fir. In: New Zealand Forest Service, Forest Research Institute, Symposium No. 15: A review of Douglas-fir in New Zealand, 273-287.

Whiteside, I. D., Wilcox, M. D., \& Tustin, J. R. (1976). New Zealand Douglas fir timber quality in relation to silviculture. New Zealand Journal of Forestry, 22(1), 24-44.

Wilhelmsson, L., Arlinger, J., Spangberg, K., Lundqvist, S.-O., Grahn, T., Hedenberg, O., \& Olsson, L. (2002). Models for predicting wood properties in stems of Picea abies and Pinus sylvestris in Sweden. Scandinavian Journal of Forest Research, 17, 330-350

Wimmer, R., \& Grabner, M. (2000). A comparison of tree-ring features in Picea abies as correlated with climate. IAWA Journal, 21(4), 403-416.

Zhang, S. Y., Chauret, G., Swift, D. E., \& Duchesne, I. (2006). Effects of precommercial thinning on tree growth and lumber quality in a jack pine stand in New Brunswick, Canada. Canadian Journal of Forest Research, 36(4), 945-952.

\section{Submit your manuscript to a SpringerOpen ${ }^{\mathcal{O}}$ journal and benefit from:}

- Convenient online submission

- Rigorous peer review

- Open access: articles freely available online

- High visibility within the field

Retaining the copyright to your article

Submit your next manuscript at $>$ springeropen.com 